\title{
Contribution of fish farming to the socio-economic status of fish farmers in Oyo State, Nigeria
}

\author{
A. A. AYELOJA*, G. L. ADEBISI \& L. A. OYEBODE \\ (A.A.A.: Department of Aquaculture and Fisheries, University of Ilorin, PMB 1515 Ilorin, \\ Kwara State; \\ G.L.A.: Department of Agricultural Extension and Management, Federal College of \\ Animal Health and Production Technology, Moor Plantation, Ibadan; L.A.O.: Department \\ of Agriculture, College of Agriculture Food Science and Technology, Wesley University of \\ Science and Technology, Ondo, Ondo state) \\ *Corresponding author's email: ayeloja2@gmail.com/ayeloja.aa@unilorin.edu.ng
}

\begin{abstract}
This study determined the contribution of fish farming to the socio-economic status of fish farmers in Oyo State. A multistage sampling procedure was used to select the respondents resulting in a total number of 120 fish farmers used for this study. The primary data for this study was collected using an interview schedule which was analyzed using descriptive and inferential statistics. Results revealed that the major constraint to fish farming was lack of access to credit facilities and the contribution of fish farming to the socio-economic status of fish farmers was high. At 0.05 level of significance, significant relationships exist between the respondents age $(r=0.389, p=0.004)$, household size $(r=0.286, p=0.002)$, years of experience $(r=0.298, p=0.001)$, benefits $(\mathrm{r}=0.279, \mathrm{p}=0.002)$ and their socio-economic status. Chi-square analysis of the result shows that there was significant relationship between marital status $\left(\chi^{2}=5.835, \mathrm{p}=0.023\right)$ and socio-economic status. Based on these findings, the study recommended that credit facilities should be made available to fish farmers and conventional feeds should be available to users at a reduced rate.
\end{abstract}

Keywords: Contribution; fish farming; socio-economic; status; fish farmers Original scientific paper. Received 23 May 2019; revised 17 Jun 2021

\section{Introduction}

There is increasing demand for fish products worldwide which has resulted in the growth of fish farms to meet a substantial part of the world's food requirement (FAO, 2007). Fish farming is predominantly an extensive landbased system practiced majorly at the smallscale subsistent level in Africa (Anyawu, 2005). Fagbenro (2005) also reported that in Nigeria, large-scale commercial fish farming is yet to become widespread with most fish farmers operating small-scale fish farm enterprises ranging from homestead concrete ponds $(25$ to $40 \mathrm{~m})$ to small earthen ponds (0.02 to 0.2 ha). Jagger and Pender (2001) also opined that fish farming is uniquely placed to reverse the declines in supplies experienced from capture fisheries and has notable potentials for new livelihood opportunities, providing a mechanism for lower-priced fish,

Ghana Jnl Agric. Sci. 56 (2), 75 - 84

GJAS is an Open Access Journal and distributed under the terms of the Creative Commons (CC) License [CC BY 4.0] 
enhanced nutritional security and employment for poor communities. Nwafili and Tianxiang (2007) also reported that out of the estimated 120 million people in Nigeria in 2000, about one percent engages in fishing and over 24 million Nigerians depend on fisheries for their livelihood.

Fish farming has the potential to help expand the resource base for food production and reduce the pressure on conventional sources of fish which are harvested faster than they can be regenerated, for developing countries like Nigeria where the economy is largely agrarian, fish farming can generate significant employment and enhance the socio-economic status of the farmer as well as generate foreign exchange (Oluwasola \& Ajayi, 2013). Goswami and Sathiadhas (2000) stated that community fish farming played a significant role in the socio-economic status of villagers. It is against this background that the contribution of fish farming to the socioeconomic status of fish farmers in Oyo state was embarked upon.

The general objective of the study was to determine the contribution of fish farming to the socio-economic status of fish farmers in Oyo state while the specific objectives of the study were to;

1. describe the socio-economic characteristics of fish farmers.

2. determine the enterprise characteristics of fish farming.

3. examine fish farmers' involvement in fish farming activities

4. ascertain the benefits fish farmers derived from their involvement in fish farming.

5. determine the contributions of fish farming to the socio-economic status of fish farmers.

6. identify the respondents' constraints to fish farming.

\section{Materials and Methods}

The study was carried out in Oyo state which covered approximately an area of 28,454 square kilometers and is ranked $14^{\text {th }}$ by size. The landscape consists of old hard rocks and domeshaped hills, which rise gently from about 500 meters in the southern part and reaching a height of about 1,219 meters above sea level in the northern part. The climate is equatorial, notably with dry and wet seasons with relatively high humidity. The dry season lasts from November to March while the wet season starts from April and ends in October, average daily temperature ranges between $25^{\circ} \mathrm{C}\left(77.0^{\circ} \mathrm{F}\right)$ and $35^{\circ} \mathrm{C}(95.0$ ${ }^{\circ} \mathrm{F}$ ), almost throughout the year. Multistage sampling procedures were used to select the sample size for this study. The first stage involved a simple random selection of $20 \%$ of 33 local government areas of Oyo state while the second stage involved the disaggregation of fish farmers into registered fish farmers and unregistered in the selected local government areas in another stage which involved a simple random selection of $40 \%$ of the 150 registered fish farmers in the selected local government areas obtained from the zonal office of the Oyo state agricultural development programme. Also, the list of the equivalent unregistered fish farmers in selected local government areas was generated using the snowball technique and $40 \%$ of the unregistered fish farmers were randomly selected which made up 60 respondents. Therefore, the total sample size used for the study was 120 respondents.

Data collection, analysis and measurement of variables

Data for the study were obtained through the use of interview schedule. Descriptive and inferential statistics were used to analyze the data. The descriptive statistics involved the 
use of frequency, percentage while inferential statistics involved the use of chi-square and PPMC (Pearson Product Moment Correlation).

The independent variables for this study include socio-economic characteristics, enterprise characteristics, fish farmer's involvement in fish farming, benefits of fish farming, constraints to fish farming while the dependent variable is socio-economic status. Socio-economic characteristics were ascertained by asking the respondents to indicate their age, sex, marital status, level of education attained and income. Enterprise characteristics of the respondents were elicited by asking them to indicate their source of labour, source of finance, years of farming experience, training on fish farming, types of pond used, pond stocking capacity, numbers of pond own, fish varieties, method of land acquisition. Fish farmers' involvement in fish farming activities was measured by asking the respondents to indicate their degree of involvement in fish farming activities such as always involved, occasionally involved and not involved with the assigned numbers of 1, 2, 0 respectively. The benefits fish farmers derived from fish farming were measured by asking them to indicate the level of benefits from information provided whether it is high, slight and not a benefit with the assigned numbers of $1,2,0$. With regards to constraints to fish farming, the respondents were asked to indicate their constraints and its degree whether it is major, minor and not a constraint on the basis of information provided.

Socio-economic status (dependent variable) was measured by using the scale constructed by Ovwigho (2000). This was measured based on the possession of items and quantity for continuous items as a result of fish farmer involvement in fish farming, however, there is an indication of "YES" for possession of items and "NO" for non possession of items that are categorical among the respondents.

\section{Results and Discussion}

Respondents' socio-economic characteristics Age distribution as presented in Table 1 shows that $46.7 \%$ of the respondents were between the ages of 31 and 40 years and $23.3 \%$ of them were between the ages of 41 and 50 years. The implication of this result indicated that most of the respondents $(46.7 \%)$ were in their productive years with the hope to better or improve their socio-economic condition. This result is consistent with Adewuyi et al. (2010) from their studies on the analysis of profitability of fish farming in Ogun state. Also, the majority of the respondents (80.8\%) were male while $19.2 \%$ of the respondents were female. This means that males were more involved in fish farming than females which is in agreement with the findings of Adewuyi et al (2010). Available data in Table 1 also revealed that $77.5 \%$ of the respondents were married, $20.0 \%$ of them were single and $2.5 \%$ of them divorced. This implies that majority of the respondents were married. On the respondents' religious affiliation, the result also showed that $72.5 \%$ of the respondents were Christians, $25.8 \%$ of the respondents were Muslims while only $1.7 \%$ of them practiced traditional religion. This means that the Christian religion is a popular religion among the respondents. Findings also revealed that $51.7 \%$ of the respondents had between 4 and 6 persons in their families and $25.8 \%$ of them had between 1 and 3 persons in their families. From these findings, it could be deduced that most of the respondents had significant household size which is likely to have influenced fish farming activities. According to Sule et al. (2002), household size has a great role to play in family 
labour provision in the agricultural sector. On the level of education of the respondents, 39.2\% of them had secondary education and 36.7\% of them had tertiary education. This implies that most of the respondents attained level of education that qualified them as literate farmers and as such will improve their knowledge and performance in fish farming activities. This outcome of this finding is consistent with the report of Aromolaran (2000). Further result from the finding in Table 1 also shows the major occupation of the respondents, 35.0\% of the respondents were into civil service and $28.3 \%$ of them were into teaching. These results signified that most of the respondents took fish farming as part-time jobs which were quite similar to that of the study carried out by Ara (2005). In terms of income realization, 57.5\% of the respondents realized between $\mathrm{N} 200,001$ and $\$ 300,000$ per cropping season.

TABLE 1

Distribution of the respondents according to their socio-economic characteristics

\begin{tabular}{llll}
\hline Variables & Frequency & Percentage & Mean \\
\hline Age & 12 & 10.0 & \\
$21-30$ & 56 & 46.7 & 1.95 \\
$31-40$ & 28 & 23.3 & \\
$41-50$ & 18 & 15.0 & \\
$51-60$ & 6 & 5.0 & \\
$61-70$ & & & \\
& & & \\
Sex & 97 & 80.8 & \\
Male & 23 & 19.2 & \\
Female & & & \\
& & & \\
Religion & 31 & 25.8 & \\
Islam & 87 & 72.5 & \\
Christianity & 2 & 1.7 & \\
Traditional & & & \\
tHousehold size & & & \\
1-3 & & & \\
4-6 & 31 & 25.8 & \\
7-9 & 62 & 51.7 & \\
10-11 & 22 & 18.3 & \\
& 5 & 4.2 &
\end{tabular}

$\begin{array}{lll}\begin{array}{l}\text { Level of education } \\ \text { No formal edu- }\end{array} & 15 & 12.5 \\ \begin{array}{l}\text { cation } \\ \text { Tertiary education }\end{array} & 44 & 36.7 \\ \begin{array}{l}\text { Primary education } \\ \text { Secondary edu- }\end{array} & 14 & 11.6 \\ \text { cation } & 47 & 39.2\end{array}$

$\begin{array}{lll}\begin{array}{l}\text { Major } \\ \text { Occupation }\end{array} & \\ \text { Teaching } & 34 & 28.3 \\ \text { Trading } & 23 & 19.2 \\ \text { Civil service } & 42 & 35.0 \\ \text { Artisan } & 11 & 9.2 \\ \text { Fishing } & 10 & 8.3\end{array}$

$\begin{array}{lll}\begin{array}{l}\text { Income (N)/crop- } \\ \text { ping season }\end{array} & & \\ 1,000-100,000 & 1 & 0.8 \\ 100,001-200,000 & 21 & 17.5 \\ 200,001-300,000 & 69 & 57.5 \\ 300,001-400,000 & 23 & 19.2 \\ 400,001-500,000 & 6 & 5.0\end{array}$

Enterprise Characteristics of the Respondents

The result of the findings presented in table 2 shows that $53.3 \%$ of the respondents used paid labour as the major source of labour in fish farming enterprise with $58.3 \%$ of them financing the business through personal saving. On the respondents' years of experience, $56.7 \%$ of the respondents had between 1 and 5 years of experience with $77.5 \%$ of the respondents had no formal training on fish farming. A substantial proportion of the respondents $(65.8 \%)$ used earthen pond for their production of fishes which is similar to the finding of Oluwasola and Ajayi (2013) in socio-economic and policy issues determining sustainable fish farming in Nigeria. Also, $41.7 \%$ of the respondents had the highest stocking capacity of 600 and above with $63.3 \%$ of them owned between 3 and 4 ponds. The commonest variety of fish the 
respondents reared was catfish with $89.2 \%$ of them engaged in its production while $46.7 \%$ of the respondents purchased the land they used for fish farming enterprise.

TABLE 2

Enterprise characteristics of the respondents

\begin{tabular}{llll}
\hline Variables & Frequency & Percentage & Mean \\
\hline Sources of & 21 & 17.5 \\
Labour & 64 & 53.3 \\
Family member & 6 & 5.0 \\
Paid labour & 29 & 24.2 \\
Friends & & \\
Self & & \\
Source of & 70 & 58.3 \\
Finance & 16 & 13.3 \\
Personal saving & 3 & 2.5 \\
Family mem- & 26 & 21.7 \\
bers & 5 & 4.2 \\
Friends & & \\
Fish Farmers & & \\
Association & & \\
Micro finance & & \\
bank & & \\
Years of & & \\
experience & & \\
1-5 & 68 & \\
6-10 & 36 & \\
11-15 & 7 & \\
16-20 & 9 & \\
Types of pond & & \\
used & 79 & \\
Earthen & 39 & \\
Concrete & 2 & \\
Tank & & \\
Pond stocking & & \\
capacity & & \\
301-400 & & \\
501-500 & & \\
600 and above & 50 & \\
\end{tabular}

Number of

pond own

$\begin{array}{llll}1-2 & 14 & 11.7 & 21.25\end{array}$

$\begin{array}{lll}3-4 & 76 & 63.3\end{array}$

$\begin{array}{lll}5-6 & 30 & 25.0\end{array}$

Fish varieties

Cat fish

$\begin{array}{lll}\text { Tilapia } & 107 & 89.2\end{array}$

Common carp $\quad 9 \quad 7.5$

Method of $\quad 4 \quad 3.3$

land acquisi-

$\begin{array}{lll}\text { tion } & 12 & 10.0\end{array}$

Inheritance $\quad 56 \quad 46.7$

$\begin{array}{lll}\text { Purchase } & 49 & 40.8\end{array}$

Rent or lease $\quad 3 \quad 2.5$

Gift

Fish farmers' involvement in fish farming activities

Available statistics in Table 3 shows the respondents involvement in fish farming activities such as feeding of fish (mean value $=1.875$ ), procurement of feed (mean value $=$ 1.442 ), collection of matured fish (mean value $=1.358$ ), stocking of fingerlings (mean value $=1.293$ ) and sorting (mean value $=1.18$ ) . Conversely, respondents were not mainly involved in checking temperature, spawning, and use of chemicals with mean values of $0.666,0.725$ and 0.816 respectively. 
TABLE 3

Fish farmers 'involvement in fish farming activities

\begin{tabular}{|c|c|c|c|c|c|c|c|c|c|}
\hline \multirow{2}{*}{ Variable } & \multicolumn{2}{|c|}{ Never } & \multicolumn{2}{|c|}{ Occasionally } & \multicolumn{2}{|c|}{ Always } & \multirow{2}{*}{$\begin{array}{l}\text { Weighted } \\
\text { scores }\end{array}$} & \multirow{2}{*}{ Mean } & \multirow{2}{*}{ Rank } \\
\hline & $F$ & $\%$ & $F$ & $\%$ & $F$ & $\%$ & & & \\
\hline Spawning & 49 & 40.8 & 55 & 45.8 & 16 & 13.3 & 87 & 0.725 & $10^{\mathrm{TH}}$ \\
\hline Sorting & 10 & 8.3 & 78 & 65.0 & 32 & 26.7 & 142 & 1.183 & $5^{\mathrm{TH}}$ \\
\hline Procurement of feeds & 8 & 6.7 & 51 & 42.5 & 61 & 50.8 & 173 & 1.442 & $2^{\mathrm{ND}}$ \\
\hline $\begin{array}{l}\text { Stocking of } \\
\text { fingerlings }\end{array}$ & 9 & 7.5 & 67 & 55.8 & 44 & 36.7 & 155 & 1.293 & $4^{\mathrm{TH}}$ \\
\hline Treatment of water & 22 & 18.3 & 69 & 57.5 & 29 & 24.2 & 127 & 1.058 & $8^{\mathrm{TH}}$ \\
\hline $\begin{array}{l}\text { Checking of } \\
\text { temperature }\end{array}$ & 57 & 47.5 & 46 & 38.3 & 17 & 14.2 & 80 & 0.666 & $11^{\mathrm{TH}}$ \\
\hline Feeding of fish & 3 & 2.5 & 9 & 7.5 & 108 & 90.0 & 225 & 1.875 & $1^{\mathrm{ST}}$ \\
\hline $\begin{array}{l}\text { Use of chemical to } \\
\text { control diseases }\end{array}$ & 34 & 28.3 & 74 & 61.7 & 12 & 10.0 & 98 & 0.816 & $9^{\mathrm{TH}}$ \\
\hline $\begin{array}{l}\text { Removal of waste } \\
\text { matter }\end{array}$ & 19 & 15.8 & 70 & 58.3 & 31 & 25.8 & 132 & 1.100 & $7^{\mathrm{TH}}$ \\
\hline $\begin{array}{l}\text { Collection of matured } \\
\text { fish from pond }\end{array}$ & 8 & 6.7 & 61 & 50.8 & 51 & 42.5 & 163 & 1.358 & $3^{\mathrm{RD}}$ \\
\hline Changing of water & 22 & 18.3 & 58 & 48.3 & 40 & 33.3 & 138 & 1.150 & $6^{\mathrm{TH}}$ \\
\hline
\end{tabular}

Benefits fish farmers derived from fish farming Table 4 showed that the majority of the respondents with the mean value of 1.80 , $1.59,1.58$ and 1.56 benefitted highly from fish farming in terms of provision of income, source of employment, improvement in health status, improvement in social life and improvement in materials possession. The implication of this finding indicated that fish farming brings an improvement in the socio-economic status of the respondents. This finding is corroborated by Edwards (2000) and Engle (2008) who posited that an improvement in the socio-economic status of fish farmers was consequent upon the benefits derived from fish farming.

TABLE 4

\begin{tabular}{|c|c|c|c|c|c|}
\hline \multicolumn{6}{|c|}{ Benefit farmers derived from fish farming } \\
\hline Variables & High & Slight & Not a benefit & Mean & Rank \\
\hline $\begin{array}{l}\text { Improve protein } \\
\text { in take }\end{array}$ & $69(57.5)$ & $46(38.3)$ & $5(4.2)$ & 1.53 & $6^{\text {th }}$ \\
\hline Provide income & $99(82.5)$ & $18(15.0)$ & $3(2.5)$ & 1.80 & $1 \mathrm{st}$ \\
\hline $\begin{array}{l}\text { Improve the knowl- } \\
\text { edge of fish rearing }\end{array}$ & $54(45.0)$ & $62(51.7)$ & $4(3.3)$ & 1.41 & 7th \\
\hline $\begin{array}{l}\text { Serves as source of } \\
\text { employment }\end{array}$ & $71(69.2)$ & $49(40.8)$ & - & 1.59 & 2nd \\
\hline $\begin{array}{l}\text { Food security } \\
\text { increase }\end{array}$ & $56(46.7)$ & $37(30.8)$ & $27(22.5)$ & 1.24 & $8^{\text {th }}$ \\
\hline
\end{tabular}




\begin{tabular}{|c|c|c|c|c|c|}
\hline $\begin{array}{l}\text { Use as collateral } \\
\text { for credit }\end{array}$ & $3(2.5)$ & - & $117(97.5)$ & 0.05 & $10^{\text {th }}$ \\
\hline $\begin{array}{l}\text { Improve materials } \\
\text { possession }\end{array}$ & $72(60.0)$ & $44(36.7)$ & $4(3.3)$ & 1.56 & $5^{\text {th }}$ \\
\hline $\begin{array}{l}\text { Improve health sta- } \\
\text { tus }\end{array}$ & $79(65.8)$ & $32(26.7)$ & $9(7.5)$ & 1.58 & $3 \mathrm{rd}$ \\
\hline Improve social life & $79(65.8)$ & $32(26.7)$ & $9(7.5)$ & 1.58 & $3^{\text {rd }}$ \\
\hline $\begin{array}{l}\text { Alternative income } \\
\text { source }\end{array}$ & $52(43.3)$ & $5(4.2)$ & $63(52.5)$ & 0.90 & $9^{\text {th }}$ \\
\hline
\end{tabular}

Contribution of fish farming to the socioeconomic status of the respondents

The socio-economic status of farmers was measured according to the scale developed by Ovwigho (2000). In doing this, the socioeconomic status of the fish farmers was measured in terms of the number of items possessed for continuous items and "YES" or "NO" for items that are categorical.

An assigned value of 0 and 1 for possession of items and non possession of items that are continuous and categorical were given and the result of the analysis based on the possession and non possession of items with respect to the quantity for continuous items among the respondents showed that the socioeconomic status is high among the respondents with $59.2 \%$ and low level of socio-economic status with $40.8 \%$ among the respondents with the mean value of 21.88 .

Table 5

Contribution of fish farming to socio-economic status

\begin{tabular}{llllll}
\hline $\begin{array}{l}\text { Level of contribution } \\
\text { of fish farming to } \\
\text { socio economic status }\end{array}$ & Frequency & Percentage & Mean & $\begin{array}{c}\text { Standard } \\
\text { deviation }\end{array}$ & Min \\
\hline High & 71 & 59.2 & 21.88 & 7.77 & 0.00 \\
Low & 49 & 40.8 & & 32.00
\end{tabular}

\section{Constraints to Fish Farming}

The study identified the constraints faced by fish farmers. The result in table 6 shows that considered lack of access to credit, (68.3\%), high price of conventional feed (52.5\%), land acquisition (51.7\%) and poor extension services $(50.0 \%)$, as major constraints. Lack of access to credit as a major constraint in this study is in line with the report of Oluwasola and Ajayi (2013). 
TABLE 6

Distribution of respondents according to their constraints

\begin{tabular}{|c|c|c|c|c|c|c|}
\hline Constraints & $\begin{array}{l}\text { Major } \\
\text { constraints }\end{array}$ & $\begin{array}{l}\text { Minor } \\
\text { constraints }\end{array}$ & $\begin{array}{l}\text { Not a } \\
\text { constraints }\end{array}$ & Weighted score & Mean & Rank \\
\hline $\begin{array}{l}\text { Lack of access to } \\
\text { credit }\end{array}$ & $82(68.3)$ & $30(25.0)$ & $8(6.7)$ & 194 & 1.61 & $1^{\text {st }}$ \\
\hline $\begin{array}{l}\text { Poor extension } \\
\text { services }\end{array}$ & $60(50.0)$ & $45(37.5)$ & $15(12.5)$ & 165 & 1.37 & $3^{\text {rd }}$ \\
\hline Theft & $57(47.5)$ & $42(35.0)$ & $21(17.5)$ & 156 & 1.30 & $5^{\text {th }}$ \\
\hline $\begin{array}{l}\text { Pollution of water } \\
\text { sources }\end{array}$ & $35(29.2)$ & $18(15.0)$ & $67(55.8)$ & 88 & 0.73 & $6^{\text {th }}$ \\
\hline Land acquisition & $62(51.7)$ & $39(32.5)$ & $19(15.8)$ & 163 & 1.35 & $4^{\text {th }}$ \\
\hline $\begin{array}{l}\text { High price of conven- } \\
\text { tional feed }\end{array}$ & $63(52.5)$ & $40(33.3)$ & $17(14.2)$ & 166 & 1.38 & $2^{\text {nd }}$ \\
\hline Insufficient fingerlings & $15(12.5)$ & $43(35.8)$ & $62(51.7)$ & 73 & 0.60 & $7^{\text {th }}$ \\
\hline $\begin{array}{l}\text { Inadequate water } \\
\text { supply }\end{array}$ & $15(12.5)$ & $17(14.2)$ & $88(73.3)$ & 47 & 0.39 & $9^{\text {th }}$ \\
\hline Disease attack & $17(14.2)$ & $24(20.0)$ & $79(65.8)$ & 58 & 0.48 & $8^{\text {th }}$ \\
\hline Mortality of fish & $12(10.0)$ & $22(18.3)$ & $86(71.7)$ & 46 & 0.38 & $10^{\text {th }}$ \\
\hline
\end{tabular}

Relationship between respondents socioeconomic characteristics and their socioeconomic status

The result of chi-square and correlation analysis as shown in table 7 shows that sex $\left(\chi^{2}=1.515\right.$, $\mathrm{p}=0.220)$; religion $\left(\chi^{2}=1.463, \mathrm{p}=0.481\right)$ were not related to socio-economic status. However, there was a significant relationship between marital status $\left(\chi^{2}=5.835, p=0.023\right)$ and socioeconomic status. This implies that respondents that are married will have family labour that will serve as support in fish activities.

With regards to the result of correlation analysis, number of ponds owned $(\mathrm{r}=0.011, \quad \mathrm{p}=0.902) ;$ pond stocking $\quad(\mathrm{r}=-$ $0.006, p=0.951)$ were not significantly related to socio-economic status but household size $(\mathrm{r}=0.286, \mathrm{p}=0.002)$;years of experience $(\mathrm{r}=0.298, \mathrm{p}=0.001) ; \quad$ age $\quad(\mathrm{r}=0.389, \mathrm{p}=0.004)$ were related to socio-economic status. The implication of household size on the socioeconomic status of fish farmers is that the cost that will involve in the use of hired labour will be reduced which may likely increase the income of farmers, however, years of experience will enhance the respondents' practical knowledge of rearing fish which may likely bring about increased in fish productivity. On the respondents' age, as the age increases, years of experience of the respondents increases which will have positive effects on the decision making of the venture that will result in business expansion and consequently have a positive effect on fish productivity and income of the fish farmers. 
TABLE 7

Result of chi-square and correlation analysis of the relationship between socio-economic characteristics of the respondents and their socio-economic status

\begin{tabular}{lllllll}
\hline Variables & $\chi^{2}$ & Df & r-value & Cc & p-value & Decision \\
\hline Sex & 1.515 & 1 & & 0.112 & 0.220 & NS \\
Marital Status & 5.835 & 2 & & 0.215 & 0.023 & S \\
Religion & 1.463 & 2 & & 0.110 & 0.481 & NS \\
Household size & & & 0.286 & & 0.002 & $\mathrm{~S}$ \\
Years of experience & & & 0.298 & & 0.001 & $\mathrm{~S}$ \\
Number of pond own & & & 0.011 & & 0.902 & $\mathrm{NS}$ \\
Pond stocking & & -0.006 & & 0.951 & $\mathrm{NS}$ \\
Age & & 0.389 & & 0.004 & $\mathrm{~S}$ \\
\hline
\end{tabular}

Result of correlation analysis of the benefits respondents derived from fish farming and their socio-economic status

The result of the analysis in Table 8 shows that there is a significant relationship between the benefits respondents derived from fish farming and their socio-economic status $(r=0.279$; $\mathrm{p}=0.002$ ). It implies that the benefits the respondents gained in ventures into the fish farming business led to an improvement in their socio-economic status. Hence as benefits accrued from the business increase, there is a commensurate increase in the socio-economic status of the respondents.

TABLE 8

Result of correlation analysis of the relationship between the benefits respondents derived from fish farming and their socio-economic status

\begin{tabular}{llll} 
Variable & r-value & p-value & Decision \\
Benefits & 0.279 & 0.002 & $\mathrm{~S}$ \\
\hline
\end{tabular}

Result of correlation analysis of the respondents' constraints to fish farming and their socio-economic status

The result of the analysis in Table 9 shows that there is no significant relationship between the respondents' constraints to fish farming and their socio-economic status $(\mathrm{r}=0.286 ; \mathrm{p}=0.535)$. The implication of it is that the constraints to fish farming do not have negative effects on the level of socio-economic status of the respondents.

TABLE 9

Result of correlation analysis of the respondents constraints to fish farming and their socio-economic status

\begin{tabular}{llll}
\hline Variable & r-value & p-value & Decision \\
Constraints & 0.286 & 0.535 & NS \\
\hline
\end{tabular}

\section{Conclusion and Recommendation}

Based on the empirical finding of the study, it can be concluded that the fish farmers in Oyo state were in their productive age, however, majority of them were male and most of the respondents had 4-6 persons in their family with an average income of $\$ 250,000.00 \mathrm{k}$ per cropping season. The major variety of the fish reared by the farmers was catfish which provide an alternative source of income to them and the activity they engaged mostly in fish rearing was the feeding of fish. The contribution of fish farming to the socio-economic status of fish farmers was high, however, the major constraint of fish farming was lack of access to credit facilities. A significant relationship existed between the respondents' age, years of experience, household size, benefits and socio-economic status. The study, therefore, 
recommends that; Extension services towards fish farming activities should be improved through credits facilities that should be made available to fish farmers at flexible guidelines, promoting relevant policies towards enhancing the availability and affordability of conventional feeds, adoption of appropriate measures to ensure the safety of fishes by the fish farmers.

\section{REFERNCES}

Adewuyi, S. A., Phillip, B. B., Ayinde, I. A \& Akerele, D. (2010) Analysis of Profitability of Fish Farming in Ogun state, Nigeria. Journal of Human Ecology 31 (3), 179 - 184.

Anyawu, A. B. (2005) Urban Aquaculture in Nigeria. World Society Annual Report. www.was.org/ meetings/abstractdata.

Aromolaran, A. B. (2000) Analyzing Resources use Efficiency on Fish Farms. A case study of Abeokuta zone,Ogun state; Nigeria Aquafield $1(1), 12-21$.

Ara, Y. (2005) Assessment of Small Scale Fresh Water FishFarming for SustainableLivelihoods of the Rural Poor Farmers.M.S Thesis ,Department of Fisheries Management,Bangladesh Agricultural University, Mymensingh.

Edwards, P. (2000) Aquaculture, Poverty Impacts and Livelihoods. Natural Resource Perspectives. Number 56, June 2000, 1 - 4 .

Engle, C. R. (2008) Mariculture, Economic and Social Impacts, Encyclopedia of Ocean Sciences, $3925-3932$.

Fagbenro, O. A. (2005) Evaluation of Cotton Seed Cake as Fish Feed and Pond Fertilizer in the Production of Non-cichild Fishes. Journal of Applied Fisheries and Hydrobiology 3, 9-14.
FAO (2007) Poverty in Fishing Communities: Helping to Build a World Without Hunger. Food and Agricultural Organization of United Nation, New Series.

Goswami, M. \& Sathiadhas, R. (2000) Fish Farming Through Community Participation in Assam, Naga, The ICLARM Quarterly, 23(3). JulySeptember 2000.

Jagger, P. \& Pender, J. (2001) Markets, Marketing and Production Issues for Aquaculture in East Africa: The Case of Uganda. Naga, the ICLARM Quarterly 24 (1-2), 42 - 51.

Nwafili, G \& Tianxiang, N. (2007) Capture Fisheries and Aquaculture in Nigeria: A comparative Analysis in Issues in African Rural Development, Doss Cheryl and Carol Olson eds; Winrock International Rural Economic Development. Journal of Fisheries Management and Ecology 8, 198 - 214.

Oluwasola, O. \& Ajayi, D. (2013) Socio-Economic and Policy Issues Determining Sustainable Fish Farming in Nigeria. International Journal of Livestock Production 4 (1), 1 - 8.

Ovwigho, B. O. (2000) Construction and Standardization of a Socio-economic Status Scale for Farm Families in Delta State, Nigeria. Ph.D Dissertation, University of Ibadan, Nigeria.

Sule, A. M, Ogunwale, S. A. \& Atala, T. K. (2002) Factors affecting adoption on fishing innovation among fishing entrepreneurs in Jebba Lake Community. Journal of Agricultural Extension 6, 48 - 60. 